\title{
Distribution and activity of bacterioplankton in the marginal ice zone of the Weddell-Scotia Sea during austral spring
}

\author{
C. W. Sullivan ${ }^{1}$, G. F. Cota ${ }^{2}$, D. W. Krempin ${ }^{1}$, W. O. Smith, Jr ${ }^{2}$ \\ ${ }^{1}$ Marine Biology Research Section, Department of Biological Sciences, University of Southern California, Los Angeles, \\ California 90089-0371, USA \\ ${ }^{2}$ Graduate Program in Ecology, University of Tennessee, Knoxville, Tennessee 37996-1610, USA
}

\begin{abstract}
The distribution and metabolic activity of bacterioplankton were examined in relation to biological, chemical and physical factors in the marginal ice zone south of the confluence of the Weddell-Scotia Sea during austral spring, 1983. Melt water produced by the seasonal retreat of the ice edge resulted in regions of water with reduced salinity and increased vertical stratification, which in turn increased average irradiance levels for phototrophic growth. The enhanced stability of the water column apparently influenced distributions of biomass and physiological activities of both autotrophs and heterotrophs. Elevated biomass and productivity of phytoplankton and bacterioplankton coincided spatially, with maxima occurring from 100 to $250 \mathrm{~km}$ seaward of the ice edge. Bacterial abundance and biomass in ice-covered and open water regions averaged $0.7 \times 10^{11}$ cells m$~^{-3}$ and $1.8 \mathrm{mg} \mathrm{C} \mathrm{m}^{-3}$, and $1.6 \times 10^{11}$ cells $\mathrm{m}^{-3}$ and $3.7 \mathrm{mg} \mathrm{C} \mathrm{m}^{-3}$, respectively. Bacterial biomass represented only about $3 \%$ of the total particulate organic carbon, but bacterial production integrated over the euphotic zone averaged about $11 \%$ of primary production. Our results suggest that bacterioplankton production in the marginal ice zone of the Weddell-Scotia Sea contributes significantly to the enhanced biological activity of the region.
\end{abstract}

\section{INTRODUCTION}

The marginal ice zones of the southern ocean have been identified as a region of increased phytoplankton biomass and primary productivity (El-Sayed \& Taguchi 1981, Smith \& Nelson 1985, 1986, Nelson et al. 1987. 1989). In contrast, low productivity appears to be typical of the open waters of the southern ocean (El-Sayed \& Weber 1982), with a difference of up to 2 orders of magnitude in chlorophyll a between marginal ice zones and the waters of the West Wind Drift (Hempel 1985, Smith 1987). Because of stabilization of the water column near the ice edge (due to a low density meltwater lens at the surface) and seeding by ice algae and other microorganisms, a phytoplankton bloom may be associated with the stratified region. A series of blooms may occur along the path of the receding pack-ice in austral spring and summer, proceeding from the seasonal maximum to the seasonal minimum. A characteristic zonation is often established in the wake of the retreating pack-ice (Smith \& Nelson 1985, 1986, Nelson et al. 1987, 1989, Smith 1987, Sullivan et al. 1988).
In open waters of the southern ocean, away from the marginal ice zone where there is little impact from melt waters, low phytoplankton biomass and primary production has been attributed to weak vertical stratification and deep vertical mixing which limits available irradiance (Marshall 1957, Holm-Hansen et al. 1977. Smith 1987) or from heavy grazing pressure by swarms of krill or salps (Marr 1962, Hempel 1985). In marginal ice zones, regions which have been ice-free for some time have elevated algal bimoass and productivity (Smith \& Nelson 1985, Wilson et al. 1986). At the iceedge itself, however, algal biomass and primary productivity may again be low, due to a temporal lag in the development of a bloom at low $\left(-1.5\right.$ to $\left.0^{\circ} \mathrm{C}\right)$ temperature after light penetration increases with the removal of the ice cover. As in other aquatic environments, algal blooms, if persistent, may lead to the development of elevated standing crops at other trophic levels within the ecosystem (e.g. Hempel 1985, Ainley et al. 1986).

In addition to the classical linear food chain (dominated by large diatoms and krill) in the southern ocean, there are alternate pathways in the Antarctic food web, 
such as the microbial loop (Azam et al. 1983), which have received little attention. There is a growing appreciation of the importance of smaller primary producers (i.e. pico- $[<2 \mu \mathrm{m}$ ] and nanoplankton [2 to $20 \mu \mathrm{m})$ in the foodweb based on their relative abundance or biomass (Bröckel 1981, Hewes et al. 1985, Weber \& El-Sayed 1987) and their contributions to nitrogen uptake (Glibert et al. 1982, Koike et al. 1986) and carbon fixation (Weber \& El-Sayed 1987). Alternate pathways must also encompass a detrital component of the marine food web which transfers material from either dissolved organics through heterotrophic bacteria or nonliving particulate organic matter to microzooplankton, with subsequent consumption by larger zooplankton in the community. The composition and role of autotrophic microplankton in the ice-edge community have been documented (Holm-Hansen et al. 1977. El-Sayed \& Taguchi 1981), whereas the specific composition and quantitative role of other plankton, including very small phytoplankton and small heterotrophic organisms such as bacterioplankton and microzooplankton, have received much less attention.

Most of the early work on bacterioplankton in the southern ocean was done on continental shelves and was descriptive, establishing the numbers of bacteria and their role as mineralizers of simple dissolved organic compounds. Initial studies of bacterioplankton in Antarctic waters focused on their abundance and distribution using plate count methods which seriously underestimate abundance (e.g. Sieburth 1965, Wiebe \& Hendricks 1974), whereas other studies have provided information on the potential role of these microorganisms in the turnover and mineralization of dissolved organic compounds (Gillespie et al. 1976, Morita et al. 1977. Hodson et al. 1981). More recently the potential productivity of bacteria has been investigated in antarctic waters (Fuhrman \& Azam 1980, 1982, Hanson et al. 1983a, b, Hanson \& Lowery 1985). This work contributed to our understanding of the role played by bacterioplankton as mineralizers of simple dissolved organic compounds and suggested a role for them as secondary producers of particulate matter.

Within the pelagic realm, the ice-edge region of the Weddell Sea has been the focus of an interdisciplinary study (AMERIEZ: Antarctic Marine Ecosystem Research at the Ice Edge Zone). Increased production at the primary and secondary levels presumably provide the trophic bases for observed ice-edge maxima in the other biotic components of the southern ocean ecosystem (e.g. Hempel 1985, Ainley et al. 1986), but little is known about the role of bacterioplankton in the cycling of biogenic material in these regions. The main objective of our study was to investigate the influence of the ice edge on the distribution and production of pelagic microbial communities. We hypothesized that the frontal region associated with the marginal ice zone was an area of elevated bacterioplankton biomass and enhanced secondary production. To test this hypothesis we collected data which allow us to describe the relationships between bacterioplankton (e.g. biomass, physiological indices) and related biological, chemical and physical variables. We describe herein: (1) the horizontal and vertical distribution of bacterial numbers and biomass along transects through the frontal region of the marginal ice zone; (2) the rates of bacterioplankton production and growth in these transects; (3) the rate(s) of incorporation of radiolabeled precursors into macromolecular fractions in particulate matter; and (4) comparisons of primary and secondary bacterial production in the marginal ice zone.

\section{MATERIALS AND METHODS}

A 2-ship study of the marginal ice zone of the Weddell Sea was conducted between 10 November and 2 December 1983 from the RV 'Melville' and the USCGC 'Westwind' (Fig. 1). To assist in data analyses

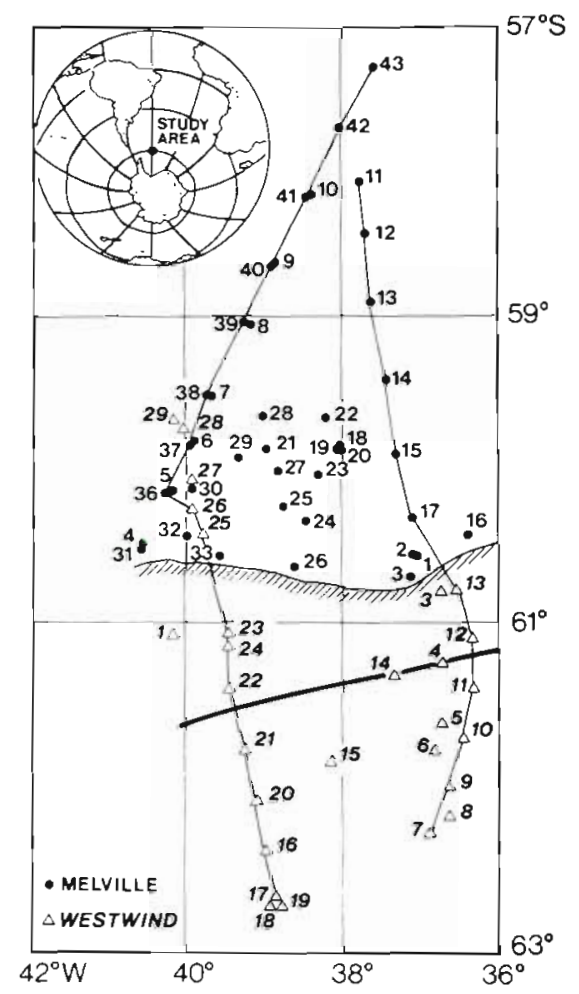

Fig. 1. Study area during 1983 showing stations occupied by the USCGC 'Westwind' $(, 1$ and by the RV Melville' (•). The approximate extent of pack ice during our study is shown by the hatched area; however, the percentage of ice cover was not constant and varied spatially. The bold line: running eastwest indicates the main gradient of ice cover in the study area as observed from shipboard. The 2 transects, involving the coordination of both ships, included the stations connected by north.south lines 
and comparisons, samples from the study area were segregated between 2 regions as follows: (1) an icecovered region (south of about $61^{\circ} \mathrm{S}$; Fig. 1 ) and (2) an open water region (north of $61^{\circ} \mathrm{S}$ ) adjacent to the pack ice, which extended from the ice edge northward into waters south of the Weddell-Scotia confluence that had presumably been recently covered by the receding seaice. A few stations were also occupied in oceanic waters $\left(58.5\right.$ to $\left.57^{\circ} \mathrm{S}\right)$ north of the confluence which probably remained largely ice-free all year. Although somewhat arbitrary, these divisions were based on the regional hydrographic regime (Nelson et al. 1987) as well as recent and historical ice cover characteristics (Zwally et al. 1983, Comiso \& Sullivan 1986).

Details of generalized methodology, the sampling scheme and results from some of the related concurrent studies have been reported (Nelson et al. 1987). They have described water mass characteristics (salinity and density), inorganic nutrient concentrations (nitrate, nitrite, phosphate and silicic acid) and particulate com-

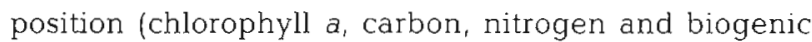
silica). Other related observations on carbon and nitrogen utilization by phytoplankton (Smith \& Nelson 1989) as well as the abundance and composition of communities of microalgae (Garrison et al. 1987) and other organisms (Ainley et al. 1986) have also been reported.

Bacterioplankton numbers and biomass were determined on water samples with methods in accord with Hobbie et al. (1977), except that cells were stained with DAPI (4',6-diamidino-2-phenylindole) to enumerate and size bacteria (Porter \& Feig 1980). Samples were stained with $10 \%$ DAPI stock solution $(2 \mathrm{mg}[100 \mathrm{ml}$ distilled water $]^{-1}$ ) for $5 \mathrm{~min}$ and filtered onto $0.2 \mu \mathrm{m}$ pore size Nuclepore filtres prestained with Irgalan Black dye. A minimum of 10 fields and 100 to 400 cells were counted per sample. Six size classes of bacterioplankton cells (cocci $0.4-0.8$ um diameter; rods $0.4-0.6$, $0.6-1.0,1.0-1.4,1.4-2.0$ and $2.0-2.8 \mu \mathrm{m}$ long) were enumerated and corresponding estimates of cell volumes $\left(\mu \mathrm{m}^{3} \mathrm{cell}^{-1}\right)$ were used to calculate bacterioplankton biomass ( $\mathrm{fgC} \mathrm{cell}{ }^{-1}$ ) (see Krempin 1986 for details). To convert cell volume to carbon, a factor of $220 \times$

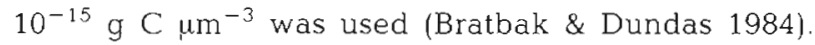
However, only total cell numbers and biomass per cubic meter are considered in our data analyses unless stated otherwise.

Rates of incorporation of tritiated thymidine (methyl${ }^{3} \mathrm{H}$-thymidine), uridine $\left(5,6-{ }^{3} \mathrm{H}\right.$-uridine) or mixed amino acids ( ${ }^{3} \mathrm{H}$-mixed $\mathrm{L}$-amino acids) into macromolecular materials insoluble in cold $5 \%$ TCA (trichloroacetic acid) were measured to obtain crude estimates of the net synthetic rates of DNA, RNA or protein, respectively (Krempin 1986). Duplicate $100 \mathrm{ml}$ samples were incubated with a labeled substrate in the dark for 3 to $6 \mathrm{~h}$ at ca $-1.0^{\circ} \mathrm{C}$ in a seawater ice-bath. The final activity of tritium $\left({ }^{3} \mathrm{H}\right)$ was $2.2 \times 10^{5} \mathrm{dpm} \mathrm{ml}{ }^{-1}$ for all samples and ${ }^{3} \mathrm{H}$-thymidine and ${ }^{3} \mathrm{H}$-uridine were present at a final added concentration of $10 \mathrm{nM}$. The added concentration of tritiated amino acids was about $0.35 \mathrm{nM}$, assuming an average molecular weight of 150 for the 15 amino acids in the mixture. Formalin-killed controls ( $1 \%$ final concentration) were incubated in an identical fashion to estimate passive adsorption. Labeled material was collected on $0.45 \mu \mathrm{m}$ HA Millipore filters, rinsed twice with $10 \mathrm{ml}$ cold TCA and once with filtered seawater, radioassayed, corrected for adsorption and converted to molar equivalents. The acid-insoluble fraction from selected samples were subjected to enzymatic hydrolysis with DNAse, RNAse or protease according to Krempin (1986).

Rates of thymidine incorporation were also measured as a function of time to establish linearity for at least $12 \mathrm{~h}$ and as a function of substrate concentration to determine saturating concentrations (Krempin 1986). The specific activity of the ${ }^{3} \mathrm{H}$-thymidine was corrected accordingly, before calculating the rate of thymidine uptake. The maximum thymidine uptake velocity $\left(V_{\max }\right)$ was about 5 pmol $1^{-1} \mathrm{~h}^{-1}$ with a $K_{\mathrm{t}}$ for thymidine transport ([S] at $1 / 2 \mathrm{~V}_{\text {max }}$ ) of $\mathrm{Ca} 0.1 \mathrm{nM}$ (Krempin 1986). The $10 \mathrm{nM}$ thymidine we employed in our experiments should have saturated thymidine uptake and prevented artifacts due to concentration-limited uptake. Cell production rates for bacteria were estimated in all samples from the rates of ${ }^{3} \mathrm{H}$-thymidine incorporation (Fuhrman \& Azam 1980, 1982) using a conversion factor of $2.05 \times 10^{18} \mathrm{cells} \mathrm{mol}^{-1}$ of thymidine incorporated (Riemann et al. 1982). Rates of production $\left(\mathrm{mg} \mathrm{C} \mathrm{m}^{-3}\right.$ $\mathrm{d}^{-1}$ ) by bacterioplankton were determined from bacterial cell production and average cell biomass as carbon. Primary productivity was measured in deck boxes under simulated in situ conditions at 7 light levels, from 100 to $0.1 \%$ of incident irradiance (Smith \& Nelson 1990). Values for ice-covered regions represent patential rates because no attempt was made to simulate in situ light as a function of snow and ice cover. Areal estimates of algal or bacterial biomass and productivity were integrated over the euphotic zone or to $100 \mathrm{~m}$ when light penetration data were not available. The euphotic zone ranged from 41 to $106 \mathrm{~m}$ during the cruise. Bacterial productivity and growth rates were only measured to $50 \mathrm{~m}$ in ice-covered waters, but we have extrapolated areal estimates to the $0.1 \%$ light level or $100 \mathrm{~m}$ in some cases for consistency in comparisons between autotrophs and heterotrophs. The lack of significant structure beneath the ice (i.e. low and relatively constant values) observed in this study and a subsequent one (Cota et al. 1989) suggest this is reasonable.

Carbon-based growth rates for phytoplankton were calculated in a manner similar to Eppley (1968). This 
method assumes that all particulate organic carbon was exclusively phytoplankton carbon without any contamination by detritus or heterotrophs, which will result in underestimates of algal growth rates unless algal carbon overwhelmingly dominates total particulate organic carbon. Average daily growth rates for bacteria $(\mu)$ were based on thymidine content and rates of incorporation of labeled ${ }^{3} \mathrm{H}$-thymidine:

$$
\mu=1 / t \times \ln [(T+\Delta T) / T]
$$
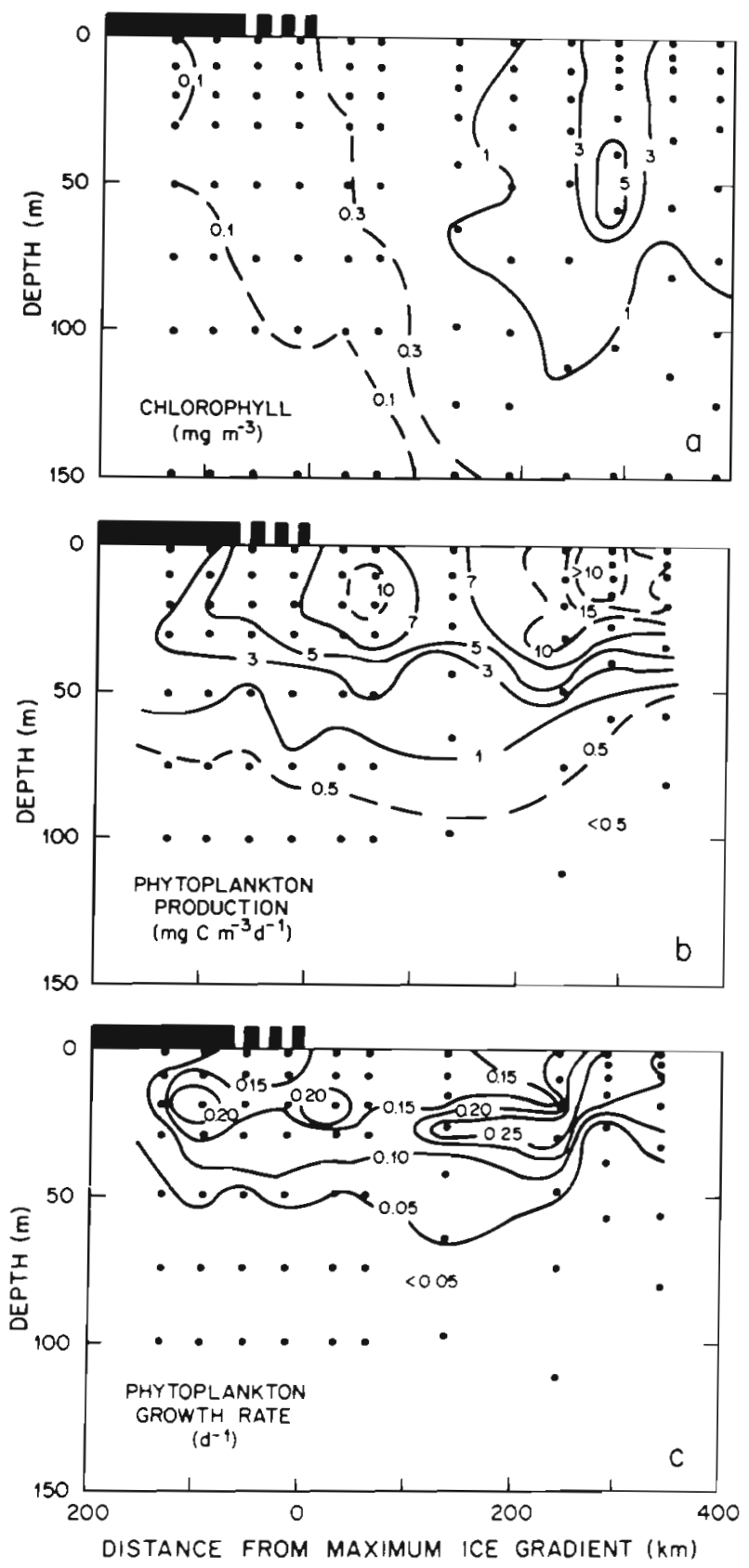

where $\mathrm{t}=$ time interval in days; $\mathrm{T}=$ cellular content of thymidine, assumed to be $1 \mathrm{~mol}$ thymidine for $2.05 \times$ $10^{18}$ cells (Riemann et al. 1982); and $\Delta \mathrm{T}=$ daily accumulation of thymidine per cell. Daily thymidine accumulation was estimated from the 3 to $6 \mathrm{~h}$ incorporation measurements ( $m$ ol thymidine $\mathrm{m}^{-3} \mathrm{~h}^{-1}$ ); these short-term rates were extrapolated to a daily rate, divided by the concentration of cells (cells $\mathrm{m}^{-3}$ ) and multiplied by $\left(\mathrm{d} 24 \mathrm{~h}^{-1}\right)$.

Turnover times $\left(T_{t}\right)$ for the labeled substrates were
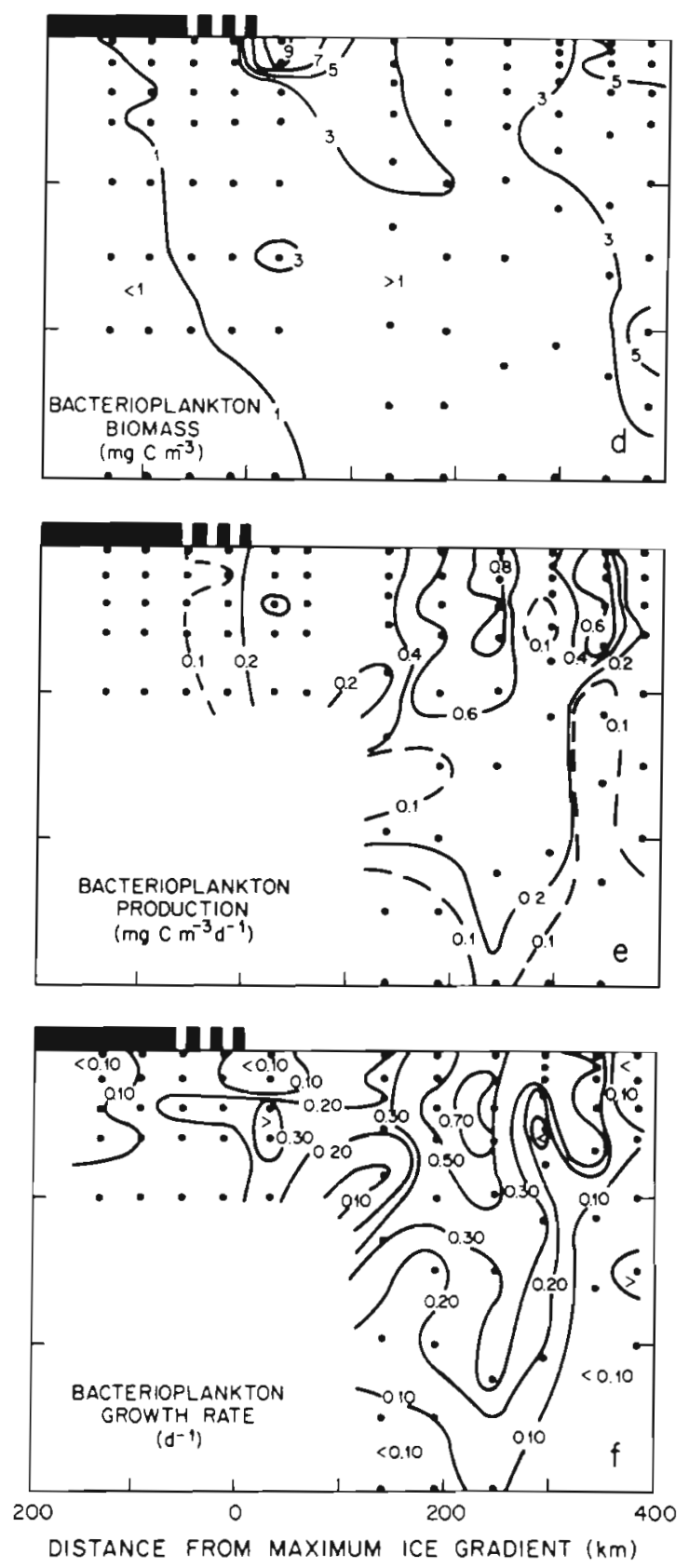

Fig. 2. Vertical sections of microbial parameters from the eastern transect. Points represent location and depth of sampling. (a) Chlorophyll $a_{i}(b)$ phytoplankton production rate; (c) phytoplankton growth rate; (d) bacterioplankton biomass; (e) bacterioplankton biomass production; and (f) bacterioplankton growth rate. Black bars at upper left indicate ice cover 
calculated with the tracer approach developed by Williams \& Askew (1968)

$$
\mathrm{T}_{\mathrm{i}}=\mathrm{t}_{\mathrm{i}} /\left(\mathrm{F}_{\mathrm{s}}\right)
$$

where $t_{i}=$ incubation time; $F_{s}=$ fraction of substrate utilized. When employing this approach, it is assumed that the concentration of added substrate does not greatly change the natural substrate concentration. No data are available on the ambient concentrations of
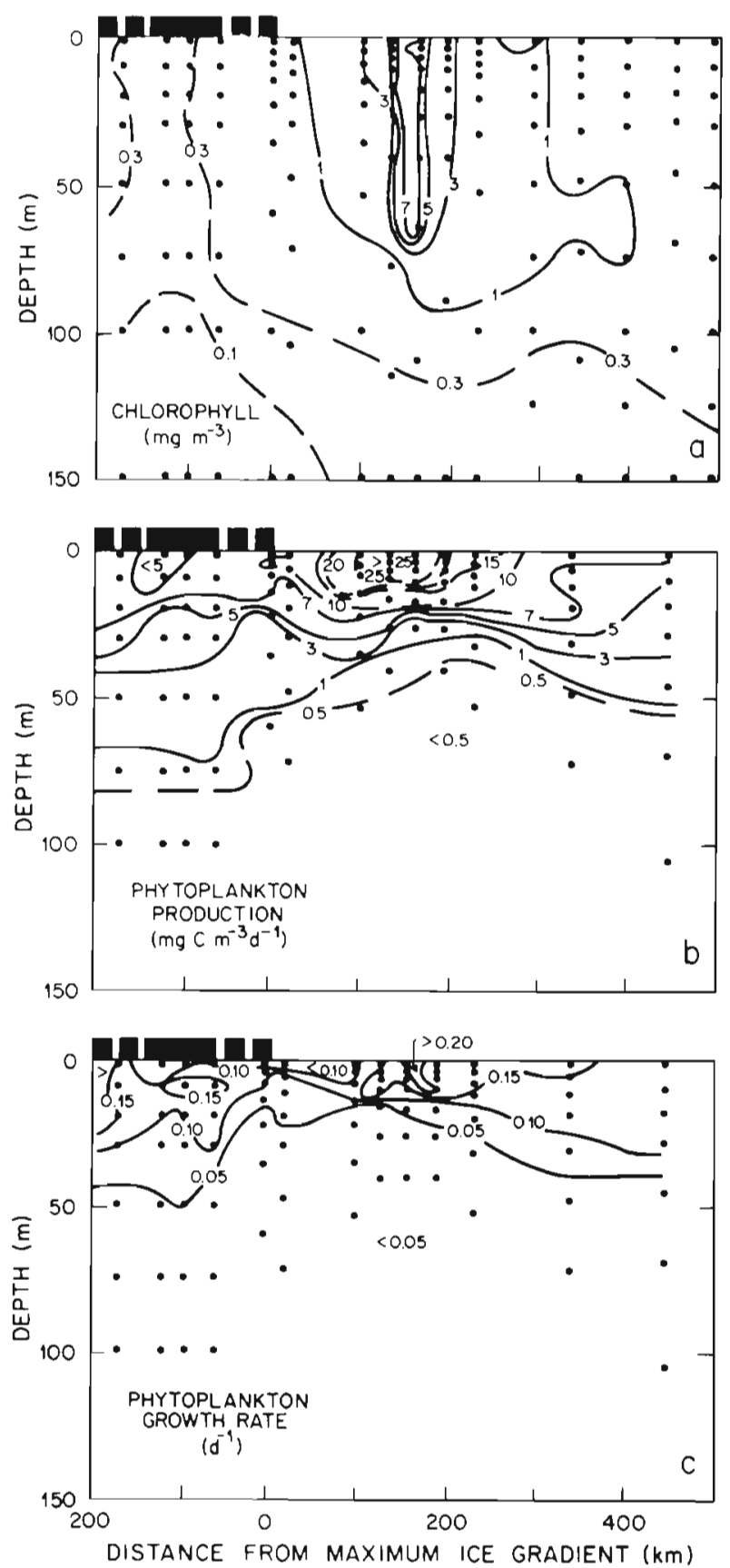

amino acids during the cruise, therefore turnover times presumably are overestimates of in situ rates (Miller et al. 1984)

\section{RESULTS}

The distributions of phytoplankton and bacterioplankton for the eastern and western transects reveal a number of distinct features (Figs. 2 and 3). The concen-
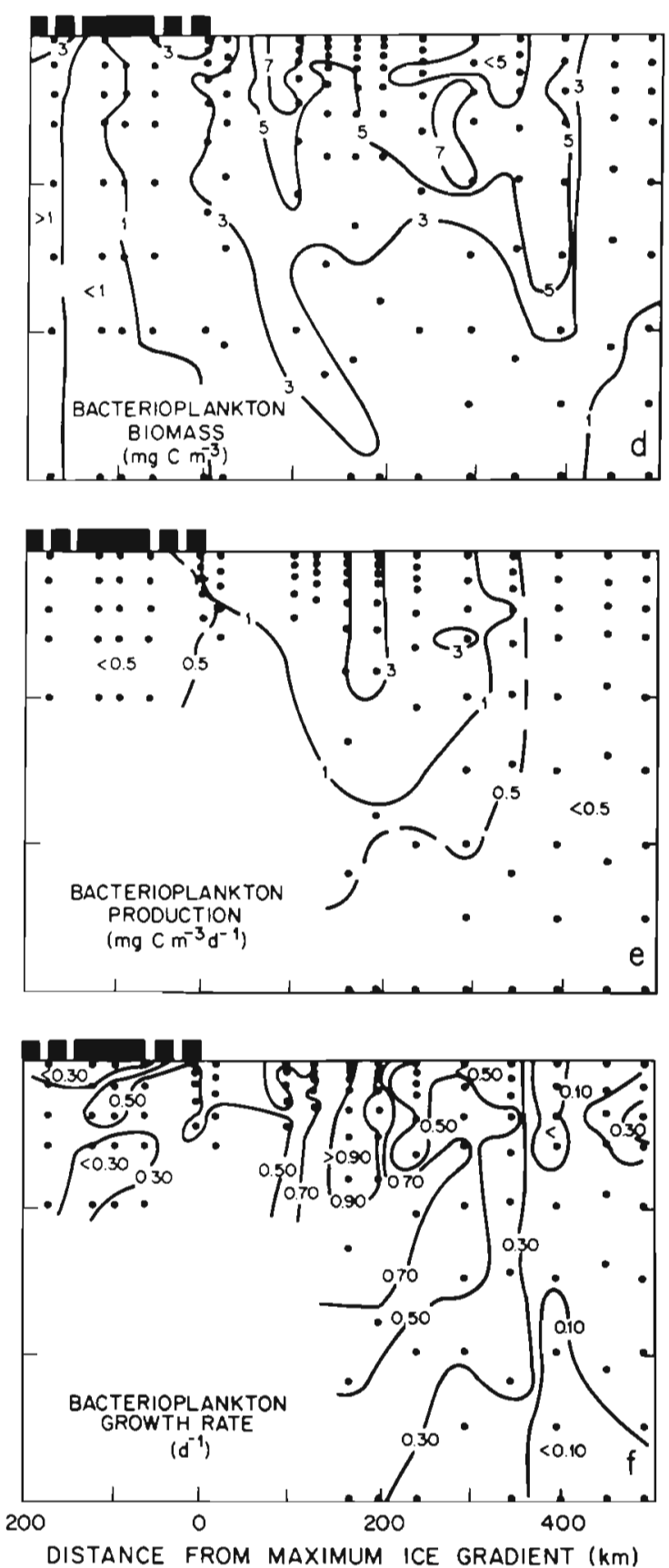

Fig. 3. Vertical sections of microbial parameters from the western transect. Points represent location and depth of sampling. (a) Chlorophyll $a_{\text {; }}$ (b) phytoplankton production rate; (c) phytoplankton growth rate; (d) bacterioplankton biomass; (e) bacterioplankton biomass production; and (f) bacterioplankton growth rate. Black bars at upper left indicate ice cover 
tration of chlorophyll a (Figs. 2a and 3a) was normally low $\left(<0.3 \mathrm{mg} \mathrm{m}^{-3}\right)$ under the ice and usually at depth. In the open water regions on both sides of the study area the levels of chlorophyll reached a maximum at about 100 to $300 \mathrm{~km}$ from the ice edge. At the center of the bloom in the western section, chlorophyll a levels of more than $7 \mathrm{mg} \mathrm{m}^{-3}$ were observed throughout the upper $70 \mathrm{~m}$ of the water column, with some values exceeding $12 \mathrm{mg} \mathrm{m}^{-3}$. The patterns of primary production (Figs. $2 \mathrm{~b}$ and $3 \mathrm{~b}$ ) were similar to those of algal biomass, except that the productivity maxima tended to be wider and more shallow than the corresponding biomass maxima, especially in the western section. In the center of the more pronounced algal biomass maximum of the western region (Fig. 3a), the rate of primary production exceeded $25 \mathrm{mg} \mathrm{C} \mathrm{m}^{-3} \mathrm{~d}^{-1}$ throughout the upper 10 to $20 \mathrm{~m}$ of the water column (Fig. 3b). A secondary maxima in primary productivity was also present just seaward of the ice edge in the eastern section (Fig. 2b). Algal growth rates were generally less than $0.15 \mathrm{~d}^{-1}$ below about $30 \mathrm{~m}$ on both transects (Figs. $2 \mathrm{c}$ and $3 \mathrm{c}$ ) with broad shallow maxima of 0.15 to $0.20 \mathrm{~d}^{-1}\left(0.22\right.$ to 0.29 doublings $\left.\mathrm{d}^{-1}\right)$. In open waters the surface values for algal growth rates averaged about 3 times those in ice-covered portions of the study area, although data from ice-covered stations should be considered to be potential growth rates as light was not adjusted as a function of ambient pack ice cover and production values are most likely overestimates of in situ rates.

Bacterioplankton exhibited distributional patterns similar to those of phytoplankton. The abundance of bacterioplankton cells was lowest $1 \leq 0.5 \times 10^{11}$ cells $\mathrm{m}^{-3}$ ) under the pack ice, but exceeded $3 \times 10^{11}$ cells $\mathrm{m}^{-3}$ in the maxima of both sections (Krempin 1986). Bacterioplankton biomass (Figs. 2d and 3d) was lowest ( $\leq 1 \mathrm{mg} \mathrm{C} \mathrm{m}{ }^{-3}$ ) under the ice and at the northern end of the western section. In both sections bacterial biomass displayed local maxima with over $7 \mathrm{mg} \mathrm{C} \mathrm{m}^{-3}$, and there was a broad region of elevated biomass with $\geq 3 \mathrm{mg} \mathrm{C} \mathrm{m}{ }^{-3}$ which was about $300 \mathrm{~km}$ wide and spanned most of the open-water portion of the western section (Fig. 3d). High levels of abundance and biomass for bacterioplankton were confined to the upper 25 to $50 \mathrm{~m}$ of the water column near the ice edge, but extended below $75 \mathrm{~m}$ in parts of the open-water regions to the north.

Bacterial productivity in both sections revealed maxima about 150 to $300 \mathrm{~km}$ seaward of the ice edge (Figs. $2 \mathrm{e}$ and $3 \mathrm{e}$ ). The maximum in bacterial production along the eastern transect reached more than $0.8 \mathrm{mg} \mathrm{C} \mathrm{m}^{-3}$ $\mathrm{d}^{-1}$, but was centered between 2 regions of elevated biomass; however, near the northern end of this section secondary maxima in biomass and production overlapped (Fig. 2). In contrast, production rates for bacteria in the western section were over $1 \mathrm{mg} \mathrm{Cm} \mathrm{Cm}^{-3} \mathrm{~d}^{-1}$ in an area almost $300 \mathrm{~km}$ wide, and this region was nearly centered on the maxima for algal biomass and production (Fig. 3). The highest rates of secondary production always occurred within the upper $75 \mathrm{~m}$ of the water column in both transects, but were usually about 5 -fold higher in the western section. Maxima in bacterioplankton growth rates (Figs. $2 \mathrm{f}$ and $3 \mathrm{f}$ ) were restricted to the upper $50 \mathrm{~m}$ and their distributions overlapped to a large degree with the algal and bacterial productivity maxima. Growth rates for bacterial populations were usually about 2 - to 3 -fold higher on the western section, attaining values greater than $1.0 \mathrm{~d}^{-1}$.

Net rates of macromolecular synthesis were measured only on the western transect (Fig. 4) and values were usually lowest under the heavier pack ice, at depth and to the extreme north of the study area. Rates of macromolecular synthesis were maximal near the center of the section with values in excess of 50,400 and $100 \mathrm{nM} \mathrm{m}^{-3} \mathrm{~d}^{-1}$, respectively, for thymidine, uridine and the amino acid assemblage. The high rates of synthesis were largely confined to the upper $50 \mathrm{~m}$ and all of the maxima occurred within the region with the highest algal biomass and production.

Differences between the biological regimes of the ice-covered portion and the open water areas are contrasted in Table 1. Standing stocks and production rates were highest in the open water, but apparent growth rates for either algae or bacteria showed little difference. The average turnover times for mixed amino acids were also much more rapid in open waters $\left(T_{t} \approx\right.$ $13 \mathrm{~d})$ than for ice-covered regions $\left(T_{t} \approx 83 \mathrm{~d}\right.$ ).

The spatial distributions of phytoplankton and bacterioplankton within the marginal ice zone are illustrated on a finer scale in Fig. 5. The data, integrated over the euphotic zone or the top $100 \mathrm{~m}$, were divided into $100 \mathrm{~km}$ bins and plotted as the interval midpoint in relationship to the ice edge which was defined as zero (e.g. data from all stations seaward of the ice edge in the interval from 100 to $200 \mathrm{~km}$ were averaged and plotted at $150 \mathrm{~km}$ ). The biomasses of phytoplankton and bacteria were elevated in a broad region centered around $150 \mathrm{~km}$ from the ice edge. Phytoplankton productivity displayed a pattern which coincided with this same interval, but bacterial production showed a more distinct peak within the first $100 \mathrm{~km}$ of the ice edge.

Correlation analyses of environmental parameters also suggest that bacterial and algal populations were directly related (Table 2); to maximize the number of data pairs the analyses were done using pair-wise deletion (Norusis 1986). All of the bacterial parameters showed positive correlations with the algal parameters and each other. However, both bacterial abundance (BCN) and uridine (URI) incorporation rate were more strongly correlated with algal biomass as chlorophyll a 
(CHL) or particulate carbon (POC) than with phytoplankton primary production (PPP). In contrast, incorporation of thymidine (THY) and mixed amino acid (MAA) revealed a stronger relationship to primary production than chlorophyll. With the notable exception of
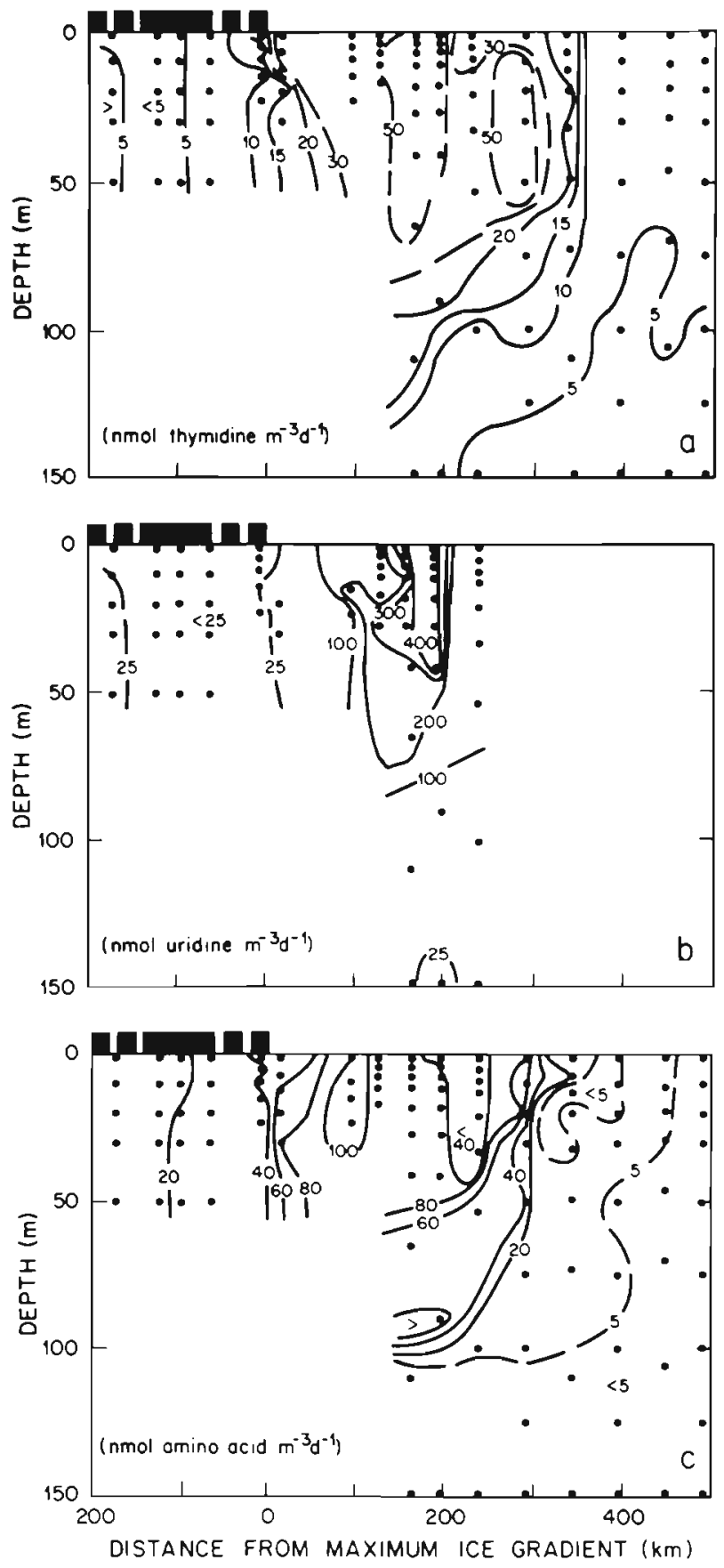

Fig. 4. Vertical sections showing macromolecular synthetic rates along the western transect. Points represent location and depth of sampling. (a) Thymidine incorporation rate (DNA synthetic rate); (b) uridine incorporation rate (RNA synthetic rate); and (c) amino acid incorporation rate (protein synthetic rate). Black bars at upper left indicate ice cover
Table 1. Microbial features measured in ice-covered waters (ca 61 to $63^{\circ} \mathrm{S}$ ) and open waters (ca 57 to $61^{\circ} \mathrm{S}$ ) of the marginal ice edge zone. All areal estimates were either integrated over the euphotic zone (i.e. $\geq 0.1 \%$ light level) or to a depth of 100 $\mathrm{m}$. Values are means \pm standard deviations (see text)

\begin{tabular}{|c|c|c|}
\hline & \multicolumn{2}{|c|}{ Region } \\
\hline & $\begin{array}{l}\text { Ice-covered } \\
\text { waters }\end{array}$ & $\begin{array}{l}\text { Open } \\
\text { waters }\end{array}$ \\
\hline $\begin{array}{l}\text { Chlorophyll a } \\
\left(\mathrm{mg} \mathrm{m}^{-2}\right)\end{array}$ & $21 \pm 10$ & $142 \pm 81$ \\
\hline $\begin{array}{l}\text { Bacterial biomass } \\
\left(\mathrm{mg} \mathrm{C} \mathrm{m}^{-2}\right)\end{array}$ & $154 \pm 119$ & $258 \pm 89$ \\
\hline $\begin{array}{l}\text { Primary production } \\
\left(\mathrm{mg} \mathrm{C}^{-2} \mathrm{~d}^{-1}\right)\end{array}$ & $269 \pm 87^{a}$ & $521 \pm 226$ \\
\hline $\begin{array}{l}\text { Bacterial production } \\
\text { (mg C } \mathrm{m}^{-2} \mathrm{~d}^{-1} \text { ) }\end{array}$ & $20 \pm 18$ & $70 \pm 65$ \\
\hline $\begin{array}{l}\text { Algal growth rate } \\
\left(d^{-1}\right)\end{array}$ & $0.08 \pm 0.06^{a}$ & $0.11 \pm 0.08$ \\
\hline $\begin{array}{l}\text { Bacterial growth rate } \\
\left(d^{-1}\right)\end{array}$ & $0.34 \pm 0.31$ & $0.42 \pm 0.29$ \\
\hline $\begin{array}{l}\text { Amino acid turnover times } \\
\text { (d) }\end{array}$ & 83 & 13 \\
\hline
\end{tabular}
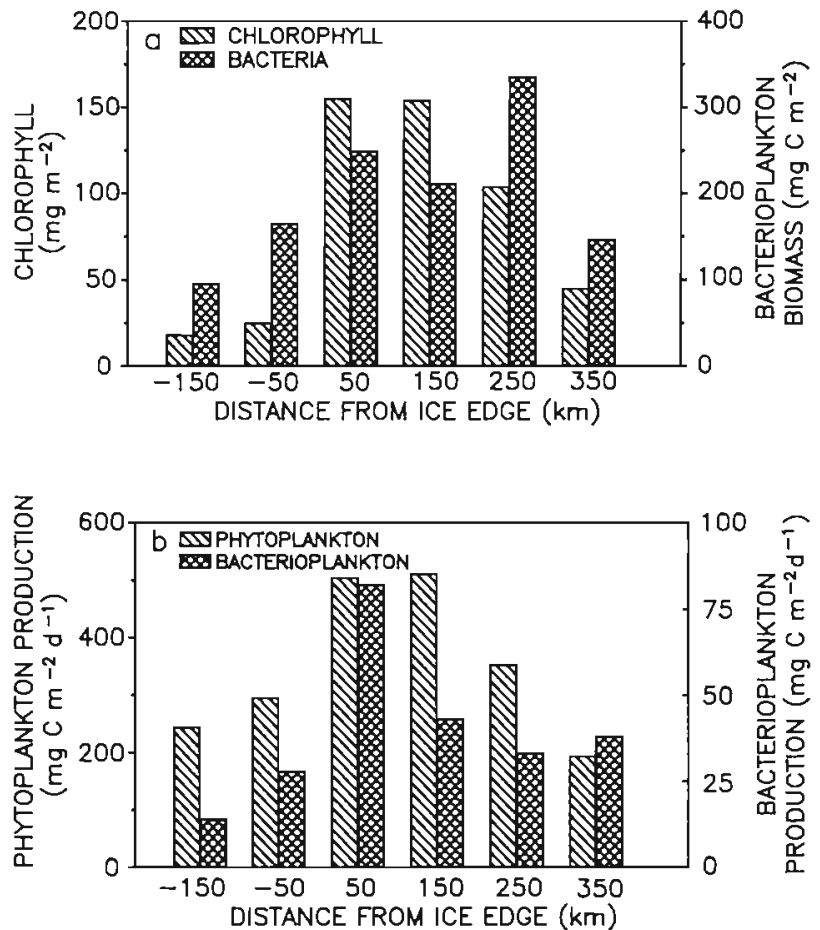

Fig. 5. Vertically integrated values of phytoplankton and bacterial biomass and production as a function of distance from the ice edge; data from $100 \mathrm{~km}$ 'bins' are plotted at interval midpoint (see text). (a) Chlorophyll and bacterial biomass as carbon; and (b) phytoplankton and bacterioplankton productivity 
Table 2. Correlation matrix for biological parameters and environmental variables from the top $150 \mathrm{~m}$ of the Weddell Sea marginal ice zone during spring. Data represent all stations from both ships. Primary productivity observations were from the euphotic zone $(55$ to $105 \mathrm{~m})$. Abbreviations: THY, thymidine; URI, uridine; MAA, mixed amino acids; BCN, bacterial cell number; PPP, phytoplankton primary productivity; $\mathrm{CHL}$, chlorophyll; POC, particulate organic carbon; $\mathrm{NO}_{3}$, nitrate; $\mathrm{PO}_{4}$, phosphate; $\mathrm{SIG}_{\text {, }}$ density in sigma-t units; TEM, temperature; and SAL, salinity. All correlations shown were significant $(p<0.05)_{i}$ missing values were not significant

\begin{tabular}{|c|c|c|c|c|c|c|c|c|c|c|c|c|}
\hline & THY & URI & MAA & $\mathrm{BCN}$ & PPP & $\mathrm{CHL}$ & POC & $\mathrm{NO}_{3}^{-}$ & $\mathrm{PO}_{4}^{2-}$ & SIG & TEM & SAI \\
\hline THY & & .68 & .47 & .29 & .44 & .37 & .59 & .13 & -.47 & & & -.13 \\
\hline URI & & & .32 & .29 & .45 & .56 & .49 & & -31 & -.15 & & -.16 \\
\hline MAA & & & & .36 & .22 & .14 & .40 & & -33 & -.20 & -.23 & -.27 \\
\hline $\mathrm{BCN}$ & & & & & .26 & .38 & .39 & & -.45 & -.34 & 18 & -.48 \\
\hline PPP & & & & & & .62 & .58 & & -49 & & & -.22 \\
\hline $\mathrm{CHL}$ & & & & & & & .68 & -.11 & -.54 & -19 & & -.34 \\
\hline POC & & & & & & & & & -.56 & -.18 & & -.23 \\
\hline $\mathrm{NO}_{3}^{-}$ & & & & & & & & & .19 & & & .13 \\
\hline $\mathrm{PO}_{4}^{2-}$ & & & & & & & & & & .27 & & .51 \\
\hline SIG & & & & & & & & & & & -.16 & .66 \\
\hline TEM & & & & & & & & & & & & -.14 \\
\hline SAL & & & & & & & & & & & & \\
\hline
\end{tabular}

ammonium, which was not positively correlated with any of the biological parameters, inorganic nutrients were usually inversely related to phytoplankton parameters, with phosphate and then nitrate being the best correlates. If bacteria were responsible for most nitrogen regeneration (i.e. ammonium production) and there was net production, then one might expect some index of their biomass or metabolism to be correlated with ammonium. However, this was never observed (Table 2). Thymidine (THY) incorporation, an index of DNA synthesis and presumably growth, was positively correlated with uridine (URI; $r=0.68$ ), mixed amino acid incorporation (MAA; $r=0.47$ ) and bacterial abundance $\left(B C N_{i} r=0.29\right)$. These correlations between bacterial macromolecular synthetic activities and abundance indicate close coupling between growth and the net synthetic activities for RNA and protein.

\section{DISCUSSION}

\section{Zonation of the marginal ice zone}

Smith \& Nelson $(1985,1986)$ and Sullivan et al. (1988) have suggested that there is a general series of events at receding ice edges in the southern oceans, thus creating a characteristic mesoscale zonation. In areas of active sea-ice melting, relatively fresh water and concentrated populations of microorganisms, including microalgae, bacteria and protozoans, are released into the surface layers. The comparatively stable layer of meltwater retards vertical mixing, allowing extant phytoplankton and those ice-algal species which are capable of growth in the meltwater lens to increase and accumulate, forming a local biomass maximum. At its seaward edge the meltwater lens is continuously being degraded by vertical mixing and other exchange processes which may result in the redistribution of microbial biomass over a greater vertical extent as distance seaward from the ice edge increases.

Mesoscale zonation of physical and chemical oceanographic parameters within the marginal ice zone has been described with respect to the ice edge (Gordon et al. 1980, Muench 1983, Niebauer \& Alexander 1985, Nelson et al. 1987, 1989) as has the distribution of primary productivity and phytoplankton biomass (El-Sayed \& Taguchi 1981, Smith \& Nelson 1985, Wilson et al. 1986). However, there have been no parallel descriptions of the distribution and metabolic activities of bacterioplankton in relation to primary producers and environmental variables within the marginal ice zone. Our data reveal a similar spatial zonation for both primary and secondary producers in the marginal ice zone, and in general, our observations fit the proposed sequence of recurrent events predicted to occur at receding ice edges and as observed by satellite remote sensing (Sullivan et al. 1988, Comiso et al. 1990).

The 'marginal ice zone' of our study area was a complex and diffuse region with variable ice cover and hydrography in both space and time (Comiso \& Sullivan 1986, Nelson et al. 1987, Sullivan et al. 1988). Areas with almost complete ice cover were 50 to $100 \mathrm{~km}$ south of the maximum extent of ice cover (Fig. 1), and concentrations of pack ice varied over the intervening region (Comiso \& Sullivan 1986). The density and salinity fields presented by Nelson et al. (1987) for the eastern and western transects were both characterized by diffuse minima seaward of the ice edge, apparently created by intermittent introductions of meltwater as the ice edge retreated southward and as the ice edge 
was compacted by wind. These minima were discrete 'packets' and not continuous horizontal features, suggesting that meltwaters may have been introduced episodically during periods of relatively rapid melting. In both sections the density minima were almost $100 \mathrm{~m}$ thick and extended ca 100 to $250 \mathrm{~km}$ seaward from the ice edge. The nitrate distributions for these transects also revealed localized minima which coincided with maxima in phytoplankton biomass (Nelson et al. 1987). Although similar features were evident in the phosphate data, the sections for silicic acid had less distinct local minima and revealed marked frontal structure at the northern end of both transects with strong latitudinal concentration gradients. The frontal region at the northern extreme was attributed to the Scotia-Weddell confluence.

\section{Bacterioplankton biomass and metabolic activity}

The mesoscale distributions of biological parameters in the marginal ice zone indicate a considerable degree of coherence between the phytoplankton and the bacterioplankton (Figs. 2 and 3). Moreover, the presence of pack ice influences the distributions of both the photoautotrophs and the heterotrophic bacteria. Under nearly continuous pack ice on the southern end of the eastern section the biomass levels were uniformly low (Fig. 2a, c), whereas along the western transect biomass concentrations appeared to increase slightly in an area where the ice cover was much more diffuse (Fig. $3 a, c)$. The spatial correlation between bacterial and algal biomass was also much stronger in the more productive westem part of the study region. Bacterial biomass ranged from about 0.2 to over $15 \mathrm{mg} \mathrm{C} \mathrm{m}^{-3}$ throughout the marginal ice zone, but varied much less between the 2 sections than did algal biomass, which was considerably higher in the western transect (Figs. $2 \mathrm{a}$ and $3 \mathrm{a}$ ). Similar values of bacterioplankton biomass have been reported in other parts of the southern ocean such as McMurdo Sound (Fuhrman \& Azam 1980, Kottmeier et al. 1987), in the southern Drake Passage near the ice edge (Hanson et al. 1983b), in the Scotia Sea (Azam et al. 1981) and in the Weddell Sea during austral fall (Cota et al. 1990). Depth-integrated means of bacterial biomass in the euphotic zone in this study were 154 and $258 \mathrm{mg} \mathrm{C} \mathrm{m}{ }^{-2}$, respectively, for icecovered and open-water regions (Table 1). Bacterial biomass represented only about $3 \%$ of total particulate organic carbon in the entire area, with little variation between ice-covered and open-water regions.

Secondary production by bacterioplankton displayed a trend similar to that of primary production during the spring, with higher values in open waters (Table 1). Furthermore, the western side of the study area dis- played much higher productivity for both groups under pack ice and in open water (Fig. 3) compared to the eastern section (Fig. 2). Bacterial production averaged $0.3 \mathrm{mg} \mathrm{C} \mathrm{m}^{-3} \mathrm{~d}^{-1}$ beneath pack ice and $1.2 \mathrm{mg} \mathrm{C} \mathrm{m}^{-3}$ $\mathrm{d}^{-1}$ in open water, but ranged up to $17.3 \mathrm{mg} \mathrm{C} \mathrm{m}^{-3} \mathrm{~d}^{-1}$ in the center of the algal bloom near the western side of the region. Previous estimates of production rates for bacterioplankton range from about 2 to $15 \mathrm{mg} \mathrm{C} \mathrm{m}^{-3}$ $\mathrm{d}^{-1}$ in coastal regions, and from 0.6 to $2 \mathrm{mg} \mathrm{C} \mathrm{m}^{-3} \mathrm{~d}^{-1}$ in oligotrophic, open-ocean areas (Ducklow 1983). Fuhrman \& Azam (1980) reported rates of 0.0004 to $2.9 \mathrm{mg} \mathrm{C} \mathrm{m} \mathrm{m}^{-3} \mathrm{~d}^{-1}$ for bacterioplankton production in McMurdo Sound, Antarctica. Hanson et al. (1983a) estimated bacterioplankton secondary production to be only $0.62 \mathrm{mg} \mathrm{C} \mathrm{m}^{-3} \mathrm{~d}^{-1}$ in the eastern South Pacific and as high as $17.1 \mathrm{mg} \mathrm{C} \mathrm{m}^{-3} \mathrm{~d}^{-1}$ in the Drake Passage near the sea-ice during late winter (Hanson et al. 1983b). In the areas with heavy ice cover and the northernmost regions where there was little, if any, influence from the melting sea-ice, our rates of secondary productivity were more typical of open-ocean values (Ducklow 1983). In contrast, bacterial productivity within the center of the ice-edge bloom on the western side of our study area was $3 \mathrm{mg} \mathrm{C} \mathrm{m}-3 \mathrm{~d}^{-1}$ or more, which is similar to the lower end of the estimates for productivity in coastal regions summarized by Ducklow (1983).

Rates of bacterial production in the marginal ice zone during austral spring were generally between 2 and $25 \%$ those of primary production, and averaged 7 and $14 \%$ in ice-covered and open waters, respectively (Table 1). However, the estimate for under pack ice is probably conservative because of the lack of simulation of the under-ice irradiance field during sample incubation. Fuhrman \& Azam (1980) suggested that a large fraction ( 20 to $25 \%$ ) of the primary production may be utilized by the bacterioplankton in McMurdo Sound, and that bacterial production might often be more than $10 \%$ of primary production. Hanson et al. (1983b) compared their estimates of bacterial production with previous literature values for primary productivity and speculated that bacterial production might be on the order of 15 to $45 \%$ of primary production. Kottmeier \& Sullivan (1987) reported data for late austral winter in Bransfield Strait which suggested that bacterial productivity ranged from less than $1 \%$ to well over $174 \%$ of primary production. In the Weddell Sea in austral autumn near a stationary ice edge, Cota et al. (1990) estimated that bacterial production in the euphotic zone of ice-covered and open waters, respectively, averaged 14 and $76 \%$ of primary productivity. However, levels of phytoplankton biomass and primary productivity were also much lower in the autumn and the bloom may have been in a state of decline.

Estimates of bacterial growth rate based on the ${ }^{3} \mathrm{H}$ thymidine incorporation method and bacterial abun- 
dance were higher than estimates of algal growth rates derived from ${ }^{14} \mathrm{C}$-fixation rates and particulate carbon (Table 1). In the upper $50 \mathrm{~m}$ growth rates for autotrophs and heterotrophs were highest and overlapped to a large degree (Figs. 2 and 3). Over most of the upper $100 \mathrm{~m}$ of the water column, growth rates of bacterioplankton ranged from less than 0.1 to greater than $1.0 \mathrm{~d}^{-1}$ with a few higher values coinciding with bacterial biomass and productivity maxima. In comparison, based upon either changes in numbers or biomass. bacteria in land-fast sea-ice grew at average rates of only $0.05 \mathrm{~d}^{-1}$ in McMurdo Sound (Grossi et al. 1984) while Kottmeier \& Sullivan (1990) reported bacterial grow th rate values of $>1 \mathrm{~d}^{-1}$ in pack-ice using the ${ }^{3} \mathrm{H}$-thymidine method. But data of Hanson et al. (1983b) implied that bacterioplankton were growing at rates between 0.9 and $2.1 \mathrm{~d}^{-1}$. Regardless of methodology, most of the reported growth rates for polar bacterioplankton and bacteria in sea-ice are within the range of 0.05 to $1.0 \mathrm{~d}^{-1}$ (Kottmeier et al. 1987, Cota et al. 1990). Maximal growth rates for phytoplankton over the range of temperatures (ca -1.75 to $+0.5^{\circ} \mathrm{C}$ ) we encountered would be roughly 0.5 to $0.7 \mathrm{~d}^{-1}$ (Eppley 1972). Our estimates of growth rate for phytoplankton of up to $0.19 \mathrm{~d}^{-1}$ are presumably underestimates because of the inclusion of detritus and heterotrophic organisms in total particulate organic carbon (Eppley 1968); hence, the lower carbon based growth rates for phytoplankton are not surprising. Growth rates are typically low for both phytoplankton (e.g. Holm-Hansen et al. 1977) and sea-ice algae (e.g. Grossi et al. 1984) in antarctic waters.

Estimates of turnover times for small organic molecules provide an indirect indication of the role bacteria may play in remineralization, especially in systems with abundant inorganic nutrients where nutrient limitation of phytoplankton is unlikely and bacteria presumably do not directly compete with them for inorganic nitrogen. Morita et al. (1977) found that microbial activity was comparable to temperate regions and concluded that these microbes had the ability to utilize all of the glutamate that would have been produced by phytoplankton. Metabolic activity comparable to rates in temperate waters have also been demonstrated for bacterioplankton in McMurdo Sound (Hodson et al. 1981) and in waters between the Falkland Islands and the ice edge in the Weddell Sea (Bölter \& Dawson 1982). Most estimates of the utilization of dissolved organic carbon in Antarctic waters indicate that organic nutrients are metabolized and recycled on the order of days to months. Our estimated tumover times are within this range and the regional averages (Table 1) are also consistent with decreased metabolic rates for the populations beneath significant pack-ice cover. Microalgae may also utilize dissolved organics (e.g.
Rivkin \& Putt 1987) and there were some high concentrations of algal biomass in the open-water areas, but the prevalence of this nutritional capability amongst polar phytoplankton and the relative importance of their contributions to the cycling of organic compounds are not well known (Sullivan et al. 1985).

All of the primary bacterial parameters, including incorporation of thymidine (THY), uridine (URI), mixed amino acids (MAA) and bacterial abundance (BCN), were often more strongly correlated with particulate carbon (POC) or chlorophyll a concentration (CHL) than with the rate of primary productivity (PPP) (Table $2)$. This result is consistent with the hypothesis of Fuhrman \& Azam (1982), who suggested that under certain conditions most dissolved organics utilized by bacterioplankton may be supplied by inefficient grazing activities rather than by extracellular release by phytoplankton. However, alternate scenarios might include low initial levels of labile dissolved organics, low rates of extracellular release by healthy, growing populations of algae, poor physiological status or dormancy of bacterial cells, a time lag in the response of bacterial populations to increases in phytoplankton production of extracellular products (e.g. Smith et al. 1977), a potential difference in the temperature responses of algae versus bacteria as hypothesized by Pomeroy \& Diebel (1986), or the main pulse of dissolved organics might be released by declining algal populations. Our data do not allow us to distinguish between these possibilities, but it seems likely that several of these explanations may, in part, contribute to weak correlations in a patchy environmental mosaic.

\section{Bacteria in sea-ice and 'seeding'}

The abundance and activity of bacteria in sea-ice have recently been studied in several regions of the Antarctic (Marra et al, 1982, Grossi et al. 1984, Kottmeier et al. 1987. Kottmeier \& Sullivan 1987, 1990, Sullivan \& Palmisano 1984). Marra et al. (1982) reported 10 times higher bacterial numbers $\left(10^{12}\right.$ cells $\left.\mathrm{m}^{-3}\right)$ and chlorophyll a concentrations $\left(5 \mathrm{mg} \mathrm{m}^{-3}\right)$ in sea-ice as compared with surface waters in the Weddell Sea. Because of large differences in bacterial cell size in the ice and plankton, they estimated bacterial biomass to be 1000 times greater in the sea-ice $(700 \mathrm{mg}$ $\left.\mathrm{m}^{-3}\right)$ than in the water column $\left(0.7 \mathrm{mg} \mathrm{m}^{-3}\right)$. Sullivan \& Palmisano (1984) found a positive correlation between bacterial numbers and chlorophyll in land-fast sea-ice, but the bacterial biomass of $9.8 \mathrm{mg} \mathrm{C} \mathrm{m}^{-2}$ represented only $0.1 \%$ of the algal crop. In contrast to Marra et al. (1982), they found bacterial biomass was only about an order of magnitude greater in sea-ice than in surface waters, but noted that bacterioplankton cells were smaller (Sullivan \& Palmisano 1984). In a period of 
about 6 wk, bacterial abundance in land-fast sea-ice increased about 6 -fold with final biomass levels around $2 \mathrm{mg} \mathrm{C} \mathrm{m}{ }^{-2}$; epiphytic bacteria within the sea-ice were significantly larger, up to $26 \mathrm{fgC} \mathrm{cell}^{-1}$, compared to nonattached bacterial cells at $9 \mathrm{fgC} \mathrm{cell}^{-1}$ (Grossi et al. 1984). In Bransfield Strait in late austral winter Kottmeier \& Sullivan (1987) also found that bacterial cells in sea-ice were $\left(25.4 \mathrm{fgC} \mathrm{cell}^{-1}\right)$ larger than those in the water column (21.2 $\left.\mathrm{fgC} \mathrm{cell}^{-1}\right)$ and that production by bacterioplankton in the euphotic zone averaged $12.3 \pm$ $4.3 \mathrm{mg} \mathrm{C} \mathrm{m}^{-2} \mathrm{~d}^{-1}$ while values in sea-ice were $5.2 \pm$ $2.8 \mathrm{mg} \mathrm{C} \mathrm{m} \mathrm{m}^{-2} \mathrm{~d}^{-1}$.

The areal abundance and biomass of bacteria in 1 to $2 \mathrm{~m}$ thick ice cores from ice floes in this investigation were found to range over 4 to $60 \times 10^{11}$ cells $\mathrm{m}^{-2}$ and 7 to $160 \mathrm{mg} \mathrm{C} \mathrm{m}{ }^{-2}$, respectively (Krempin 1986, Kottmeier \& Sullivan 1990). Bacterial numbers and biomass integrated over $150 \mathrm{~m}$ of the water column were 10 to $120 \times 10^{11}$ cells $\mathrm{m}^{-2}$ and 18 to $360 \mathrm{mg} \mathrm{C} \mathrm{m}^{-2}$, respectively, in ice-covered regions (Fig. 5). Inclusion of the bacteria associated with pack-ice into these vertical integrations would increase the total bacterial cell numbers by about $40 \%$ and biomass figures by ca $60 \%$ because of the larger cells in sea-ice (Krempin 1986 , Sullivan \& Palmisano 1984, Kottmeier \& Sullivan 1987. 1990). These computations also suggest that melting sea-ice, and the subsequent dispersion of the epontic bacteria into the water column, could account for ca $15 \%$ of the bacterioplankton cells and $25 \%$ of the biomass observed in the open waters of the ice-edge zone (Table 1). Interestingly, these large bacteria may also serve as biological markers of sea-ice meltwaters.

Distributions of cell size also suggest that bacteria from the pack-ice may have seeded the water column when the sea-ice melted. The largest bacterioplankton cells ( $\geq 36 \mathrm{fgC} \mathrm{cell}^{-1}$ ) were observed in the top 5 to $10 \mathrm{~m}$ of the water column at the northernmost icecovered stations or down to a depth of $50 \mathrm{~m}$ in the adjacent open-waters, where the phytoplankton bloom occurred. The larger bacterioplankton cells observed in the open-waters may have come from melting ice in the northernmost ice-covered portion of the study region. These would then have been mixed vertically with the phytoplankton in the open-water region of the iceedge zone as the meltwater lens eroded to the north. Vertical sections of bacterioplankton numbers (Krempin 1986) and biomass (Figs. 2 and 3) showed that the vertical extent of high concentrations increased to the north on both transects. At the stations north of the Scotia-Weddell confluence, Krempin (1986) found that average cell sizes $\left(<10 \mathrm{fgC} \mathrm{cell}^{-1}\right.$ ) were similar to values reported for other parts of the world's oceans (van Es \& Meyer-Reil 1982).

Shortly after the algae and bacteria are released from the melting ice, select species may grow rapidly because of more favorable conditions such as exposure to higher average irradiance or nutrient levels. Over several days as the ice-edge retreated further south, the maxima in microbial biomass and production may have developed in the more stable, low salinity waters in concert with the increased phytoplankton growth. Bacterial activity in this region may also have been stimulated by dissolved organic material released from the ice, exudation of dissolved organics from the growing phytoplankton and/or by the lysis of microalgae from the ice or the plankton. D. Manahan (unpubl.) has found elevated concentrations of amino acids in sea ice compared with surface seawater in McMurdo Sound (see Rivkin \& Putt 1987). The seasonal maxima in secondary production by bacterioplankton probably occurs after localized peaks in phytoplankton biomass and production start to subside, but this could not be resolved without a continuous time series of observations with better spatial resolution.

Moreover, floristic data on ice algae and phytoplankton in ice-edge zones have revealed a high degree of similarity between the assemblages, providing support for the hypothesis that the water column may be seeded by the melting ice (Garrison et al. 1987). Garrison \& Buck's (1983) observations during a late summer cruise to the Weddell Sea ice-edge also showed a high degree of similarity between microalgal populations in pack ice and in the plankton, suggesting the opposite may also be true for advancing ice-edges (i.e. the plankton may seed ice communities). Furthermore, they found considerable overlap in the assemblages of protozoa and small metazoa found in the sea-ice and planktonic environments during the present study.

\section{Bacterioplankton in the pelagic food web}

Bacterial production averages 5 to $20 \%$ of the net primary production by phytoplankton in many locations in the coastal and open oceans, implying that about 10 to $50 \%$ of primary production is cycled through bacteria if one assumes their growth efficiency is $50 \%$ (Ducklow 1983). Our observations on bacterioplankton suggest that their contribution to the total production of particulate material averages around $11 \%$ of net primary productivity for the marginal ice zone in austral spring, with slightly lower values in icecovered waters and slightly higher ones in open waters (Table 1). The importance of physical structure in the distribution of bacterial biomass and metabolic activity has also been emphasized (Hanson \& Lowery 1985). More recent and extensive work in a marginal ice zone supports our contention that the ice-edge system is an important area for enhanced bacterial activity (Cota et al. 1990). 
These studies clearly demonstrate the potential productivity of antarctic bacterioplankton in oceanic areas. In addition to their potential role as mineralizers, bacterioplankton are secondary producers that are eaten by other organisms in marine food webs. Consumption of free-living bacteria by microflagellates is the presumed fate of most bacterial production (e.g. Fenchel $1982 \mathrm{a}$, b). Furthermore, the abundance of heterotrophic protozoans in Antarctic waters (Bröckel 1981, Buck \& Garrison 1983, 1988) suggests that trophic links involving fluxes of dissolved organics and bacterioplankton may contribute significantly to the high levels of total productivity observed within the marginal ice zone of the southern ocean. Buck \& Garrison (1983, 1988) found large numbers of choanoflagellates (bactivorous protozoa) in the ice-edge region of the Weddell Sea and hypothesized that trophic paths were based on bacterial production in the food web. During the 1983 AMERIEZ cruise to the ice-edge of the Weddell Sea, Garrison et al. (1984) found low numbers $\left(7.6 \times 10^{5}\right.$ organisms $\left.\mathrm{m}^{-3}\right)$ and biomass $\left(0.2 \mathrm{mg} \mathrm{C} \mathrm{m}^{-3}\right)$ of protists in the waters below ice-covered stations. However, numbers and biomass reached maxima at ice-edge stations (more than $10^{7}$ organisms $\mathrm{m}^{-3}$ and $10 \mathrm{mg} \mathrm{C} \mathrm{m} \mathrm{m}^{-3}$, respectively). By contrast, they found relatively high numbers $\left(7.5 \times 10^{8}\right.$ organisms $\left.\mathrm{m}^{-3}\right)$ and biomass concentrations $\left(94.7 \mathrm{mg} \mathrm{Cm}^{-3}\right)$ of microheterotrophic protozoa in sea-ice. Their values for abundance were within the range reported from another Antarctic study (Bröckel 1981). Garrison et al. (1984) also noted that the abundance of microzooplankton paralleled trends in primary production and bacterial production along the western transect through the marginal ice zone. These observations suggest that grazers of bacteria may also be seeded into the water column by the melting of sea-ice or may respond to enhanced levels of prey organisms found there.

In summary, bacteria and other microheterotrophs, such as protozoans, probably serve as important trophic links to larger consumers at the ice-edge. Bacterial populations in the marginal ice zone apparently respond rapidly enough to capitalize upon increased primary production in the open waters seaward of the ice-edge. Their elevated abundance and enhanced activity near the ice-edge may contribute significantly to the increased biomass among higher trophic levels in the marginal ice zone (e.g. Buck \& Garrison 1983, 1988, Ainley et al. 1986). Continued studies of marginal ice zone communities should improve our understanding of the quantitative contributions of microheterotrophic production to total productivity in the southern ocean, the interrelationships between the communities of organisms in sea-ice and the plankton, and the nutritional relationships within all trophic levels.
Acknowledgements. We thank Haifa Harb, Holly Kelly, Mike Miller, James Rich and Andy Tran for their assistance collecting and processing data. This work was supported by National Science Foundation grants DPP-8218752 and DPP-8444783 to C.W.S. and DPP-8218758 and DPP-8420213 to W.O.S.

\section{LITERATURE CITED}

Ainley, D. G., Fraser, W. R., Sullivan, C. W., Torres, J. J., Hopkins, T. L., Smith, W. O. Jr (1986). Antarctic mesopelagic micronekton: evidence from seabirds that pack ice affects community structure. Science 232: $847-849$

Azam, F., Ammerman, J. W., Cooper, N. (1981). Bacterioplankton distributional patterns and metabolic activities in the Scotia Sea. Antarctic J. U.S. 16: 164-5

Azam, F., Fenchel, T., Field, J. G., Gray, J. S., Meyer-Reil, I. A., Thingstad, F. (1983). The ecological role of watercolumn microbes in the sea. Mar. Ecol. Prog. Ser. 10: $257-263$

Bölter, M., Dawson, R. (1982). Heterotrophic utilization of biochemical compounds in Antarctic waters. Neth. J. Sea Res. 16: 315-332

Bratbak, G., Dundas, I. (1984). Bacterial dry matter content and biomass estimations. Appl. environ. Microbiol. 48: 755-757

Bröckel, K. von (1981). The importance of nanoplankton within the pelagic Antarctic Ecosystem. Kiel. Meeres. 5: $61-67$

Buck, K. R., Garrison, D. L. (1983). Protists from the ice-edge region of the Weddell Sea. Deep Sea Res. 30: 1261-1277

Buck, K. R., Garrison, D. L. (1988). Distribution and abundance of choanoflagellates (Acanthoecidae) across the iceedge zone in the Weddell Sea, Antarctica. Mar. Biol. 98: 263-269

Comiso, J. C., Maynard, N., Smith, W. O. Jr, Sullivan, C. W (1990). Satellite ocean color studies of Antarctic ice-edge in summer/autumn. J. geophys. Res. (in press)

Comiso, J. C., Sullivan, C. W. (1986). Satellite microwave and in situ observations of the Weddell Sea ice cover and its marginal ice zone. J. geophys. Res. 91: 9663-9681

Cota, G. F., Kottmeier, S. T., Robinson, D. H., Smith, W O., Sullivan, C. W (1990). Bacterioplankton in the marginal ice zone of the Weddell Sea: biomass, production and metabolic activities during austral fall. Deep Sea Res. (in press\}

Ducklow, H. W (1983). Production and fate of bacteria in the oceans. BioScience 33: 494-501

El-Sayed, S. Z., Taguchi, S. (1981). Primary production and standing crop of phytoplankton along the ice edge in the Weddell Sea. Deep Sea Res. 28: 1017-1032

El-Sayed, S. Z., Weber, L. H. (1982). Spatial and temporal variations in phytoplankton biomass in the Southwest Atlantic and the Scotia Sea. Polar Biol. 1: 83-90

Eppley, R. W. (1968). An incubation method for estimating the carbon content of phytoplankton in natural samples. Limnol. Oceanogr. 13: 574-582

Eppley, R. W (1972). Temperature and phytoplankton growth in the sea. Fish. Bull. U.S. 70: 1063-1085

Fenchel, T. (1982a). Ecology of heterotrophic microflagellates. II. Bioenergetics and growth. Mar Ecol. Prog. Ser 8: 225-231

Fenchel, T (1982b). Ecology of heterotrophic microflagellates. IV Quantitative occurrence and importance as bacterial consumers. Mar. Ecol. Prog. Ser 9: 35-42 
Fuhrman, J. A., Azam, F. (1980). Bacterioplankton secondary production estimates for coastal waters of British Columbia, Antarctica and California. Appl. environ. Microbiol. 39: 1085-1095

Fuhrman, J. A., Azam, F (1982). Thymidine incorporation as a measure of heterotrophic bacterioplankton production in marine surface water evaluation and field results. Mar. Biol. 66: 109-120

Garrison, D. L. Buck, K. R. (1983). Sea-ice algal communities in the Weddell Sea: Species composition in ice and plankton assemblages. In: Gray, J. S., Christiansen, M. E. (eds.) Marine biology of polar regions and effects of stress on marine organisms. John Wiley and Sons, New York, p. $103-122$

Garrison, D. L., Buck, K. R., Fryxell, G. (1987). Algal assemblages in Antarctic pack ice and in ice-edge plankton. J. Phycol. 23: 564-572

Garrison, D. L., Buck, K. R., Silver, M. W. (1984). Microheterotrophs in the ice edge zone. Ant. J. U.S. 19: 109-111

Gillespie, P. A., Morita, R. Y., Jones, L. P. (1976). The heterotrophic activity for amino acids, glucose and acetate in Antarctic waters. J. Oceanogr. Soc. Japan 32: 74-82

Glibert, P. M., Biggs, D. C., McCarthy, J. J. (1982). Utilization of ammonium and nitrate during austral summer in the Scotia Sea. Deep Sea Res. 29: 837-850

Gordon, A. L., Martinson, D. G., Taylor, H. W (1980). The wind-driven circulation in the Weddell-Enderby Basin. Deep Sea Res. 28: 151-163

Grossi, S. M., Kottmeier, S. T., Sullivan, C. W. (1984). Sea ice microbial communities. III. Seasonal abundance of microalgae and associated bacteria, McMurdo Sound, Antarctica. Microb. Ecol. 10: 231-242

Hanson, R. B., Lowery, H. K. (1985). Spatial distribution, structure, biomass and physiology of microbial assemblages across the southern ocean frontal zones during late austral winter Appl. environ. Microbiol. 49: 1029-1039

Hanson, R. B., Lowery, H. K., Shafer, D., Sorocco, R., Pope, D. H. (1983a). Microbes in Antarctic waters of the Drake Passage: vertical patterns of substrate uptake, productivity and biomass in January 1980. Polar Biol. 2: 179-188

Hanson, R. B., Shafer, D., Ryan, T., Pope, D. H., Lowery, H. K. (1983b). Bacterioplankton in Antarctic Ocean waters during late austral winter abundance, frequency of dividing cells, and estimates of production. Appl. environ. Microbiol. 45: 1622-1632

Hempel, G. (1985). On the biology of Polar Seas, particularly the Southern Ocean. In: Gray, J. S., Christiansen, M. E. (eds.) Marine biology of polar regions and effects of stress on marine organisms. John Wiley and Sons, New York, p. $3-32$

Hewes, C. D., Holm-Hansen, O., Sakshaug, E. (1985). Alternate carbon pathways at lower trophic levels in the Antarctic food web. In: Siegfried, W. R., Condy, P. R., Laws, R. M (eds.) Antarctic nutrient cycles and food webs. SpringerVerlag, Berlin, p. 277-283

Hobbie, J. E., Daley, R. J., Jasper, S. (1977). Use of Nuclepore filters for counting bacteria by fluorescence microscopy. Appl environ. Microbiol. 33: 1225-1228

Hodson, R. E., Azam, F., Carlucci, A. F., Fuhrman, J. A., Karl, D. M. Holm-Hansen, O. (1981). Microbial uptake of dissolved organic matter in McMurdo Sound, Antarctica. Mar. Biol. 61: 89-94

Holm-Hansen, O., El-Sayed, E. Z., Franceschini, G. A., Cuhel R. L. (1977). Primary production and the factors controlling phytoplankton growth in the Southern Ocean. In: Llano, A. (ed.) Adaptations within Antarctic ecosystems. Gulf Publishing Co., Houston, p. 11-50
Kottmeier, S. T., Grossi, S. M., Sullivan, C. W. (1987). Sea ice microbial communities. VIII. Bacterial production in annual sea jce of McMurdo Sound, Antarctica. Mar. Ecol Prog. Ser 35: 175-186

Kottmeier, S. T., Sullivan, C. W. (1987). Late winter primary and secondary production in seawater west of the Antarctic Peninsula. Mar Ecol. Prog. Ser 36: 287-298

Kottmeier, S. T., Sullivan, C. W (1990). Bacterial biomass and production in pack-ice of Antartic marginal ice-edge zones. Deep Sea Res. (in press)

Koike, I., Holm-Hansen, O., Biggs, D. C. (1986). Inorganic nitrogen metabolism by Antarctic phytoplankton with special reference to ammonium cycling. Mar. Ecol. Prog. Ser. 30: $105-116$

Krempin, D. W. (1986). The role of bacterioplankton as producers in two high-productivity marine environments. $\mathrm{Ph}$ D. thesis, Univ. Southern Calif., Los Angeles

Marr, J. W. S. (1962). The natural history and geography of the Antarctic Krill (Euphausia superba Dana). 'Discovery' Rep. 32: $33-464$

Marra, J., Burckle, L. H., Ducklow, H. W. (1982). Sea ice and water column plankton distributions in the Weddell Sea in late winter Ant. I. U.S. 17: 111-112

Marshall, P. F. (1957). Primary production in the Arctic. J. Cons. Explor Mer 23: 173-177

Miller, M. A., Krempin, D. W., Manahan, D. T., Sullivan, C. W (1984). Growth rates, distribution and abundance of bacteria in the ice-edge zone of the Weddell and Scotia Seas, Antarctica. Ant. J. Rev. 19 (5): 103-105

Morita, R. Y., Griffiths, R. P., Hayasaka, S. S. (1977). Heterotrophic activity of microorganisms in Antarctic waters. In: Llano, G. A. (ed.) Adaptations within Antarctic ecosystems. Gulf Publishing Co., Houston, p. 99-113

Muench, R. D. (1983) Mesoscale oceanographic features associated with the central Bering Sea ice edge: FebruaryMarch 1981. J. Geophys. Res, 88: 2715-2722

Nelson, D. M., Smith, W. O. Jr, Gordon, L. I., Huber, B. A. (1987). Spring distributions of density, nutrients and phytoplankton biomass in the ice edge zone of the WeddellScotia Sea. J. geophys. Res. 92: 7181-7190

Nelson, D. M., Smith, W. O. Jr, Muench, R. D., Gordon, L. I., Sullivan, C. W., Husby, D. M. (1989). Particulate matter and nutrient distributions in the ice-edge zone of the Weddell Sea: relationship to hydrography during late summer. Deep Sea Res. 36: 191-209

Niebauer, H. J., Alexander, V (1985), Oceanographic frontal structure and biological production at an ice edge. Cont. Shelf Res. 4: 367-388

Norusis, M. J. (1986). SPSS/PC+ for the IBM PC/XT/AT. SPSS Inc., Chicago

Pomeroy, L. R., Diebel, D. (1986). Temperature regulation of bacterial activity during the spring bloom in Newfoundland coastal waters. Science 233: 359-361

Porter, K. G., Feig, Y S. (1980). The use of DAPI for identifying and counting aquatic microflora. Limnol. Oceanogr 25: $943-948$

Riemann, B., Fuhrman, J. A., Azam, F. (1982). Bacterial secondary production in freshwater measured by ${ }^{3} \mathrm{H}$-thymidine incorporation method. Microb. Ecol. 8: 101-114

Rivkin, R. B., Putt, M. (1987). Heterotrophy and photoheterotrophy by Antarctic microalgae: light dependent incorporation of amino acids and glucose. J. Phycol. 23: 442-452

Sieburth, J. McN. (1965). Microbiology of the Antarctic. In Oye, P. V., Mieghum, J V (eds.) Biogeography and ecology in Antarctica. Dr W. Junk, The Hague, p. 267-295

Smith, W. O. Jr (1987). Phytoplankton dynamics in marginal ice zones. Oceanogr. mar. Biol. A. Rev. 25: 11-38 
Smith, W. O. Jr, Barber, R. T., Huntsman, S. A. (1977). Primary production off the coast of northwest Africa: excretion of dissolved organic matter and its heterotrophic uptake. Deep Sea Res. 24: 35-48

Smith, W. O. Jr, Nelson, D. M. (1985). Phytoplankton bloom produced by a receding ice edge in the Ross Sea: spatial coherence with the density field. Science 227: 163-166

Smith, W. O. Jr, Nelson, D. M. (1986). Importance of ice edge phytoplankton production in the Southern Ocean. BioScience 36: 251-257

Smith, W. O. Jr, Nelson, D. M. (1990). Phytoplankton growth and new production in the Weddell Sea marginal ice-zone during austral spring and autumn: a comparison. Limnol. Oceanogr. (in press)

Sullivan, C. W., McClain, C. R., Comiso, J. C., Smith, W. O. Jr (1988). Phytoplankton standing crops within an Antarctic ice edge assessed by satellite remote sensing. J. geophys. Res. 93 (C): 12487-12498

Sullivan, C. W., Palmisano, A. C. (1984). Sea ice microbial communities: distribution, abundance, and diversity of ice bacteria in McMurdo Sound, Antarctica, in 1980. Appl. environ. Microbiol. 47: 788-795

Sullivan, C. W., Palmisano, A. C., Kottmeier, S., Grossi, S. M., Moe, R. (1985) The influence of light on growth and development of the sea ice microbial community in McMurdo Sound. In: Siegfried, R., Candy, P. R., Laws,

This article was submitted to the editor
R. M. (eds.) 4th SCAR Symp. Antarctic Biol. Nutrient cycles and food webs. Springer-Verlag, Berlin, p. 78-83

Van Es, F. B., Meyer-Reil, L.-A. (1982). Biomass and metabolic activity of heterotrophic marine bacteria. Adv. Microb. Ecol 6: 111-170

Weber, L. H., El-Sayed, S. Z. (1987). Contribution of net, nanoand picoplankton to the phytoplankton standing crop and primary productivity in the Southern Ocean. J. Plankton Res. 9: 973-994

Wiebe, W J., Hendricks, C. W. (1974). Distribution and heterotrophic bacteria in a transect of the Antarctic Ocean. In Colwell, R. R., Morita, R. Y. (eds.) Effects of the ocean environment on microbial activities. University Park Press, Baltimore, p. 524-535

Williams, P. J. LeB., Askew, C. (1968). A method for measuring the mineralization by microorganisms of organic compounds in seawater. Deep Sea Res. 15: 365-375

Wilson, D. L., Smith, W. O. Jr, Nelson, D. M. (1986). Phytoplankton bloom dynamics of the western Ross Sea ice edge. I. Primary productivity and species-specific production. Deep Sea Res. 33: 1375-1387

Zwally, H. J., Comiso, J. C., Parkinson, C. L., Campbell, W. J., Carsey, F. D., Gloersen, P. (1983). Antarctic sea ice, 1973-1976: satellite passive-microwave observations. NASA SP-459, U.S. Government Printing Office, Washington, D.C., p. 1-206

Manuscript first received: August 17, 1989

Revised version accepted: January 5, 1990 